\title{
Sources in Eastern Orthodox Christianity: Supplemental Texts yalebooks.com/eoc
}

\section{PART I Origins and Metamorphoses}

I. Church in Scripture

I.I The Acts of the Apostles (ca. 85-95)

I.2 First Letter of Paul to the Corinthians (ca. 53-57)

I.3 Letter of Paul to the Romans (ca. 55-57)

2. Chalcedon and Non-Chalcedonian Churches

2.I Tome of Leo (449)

2.2 Statements from the Council of Chalcedon (45I)

2.3 Copts and Other Dissenters

2.4 Severus (ca. 465-538) on Chalcedon and Ordination

2.5 Severus (ca. 465-538) on Chalcedonians

2.6 John Rufus (476-5 I 8), Life of Peter the Iberian

3. Priests and Bishops

3.I John Chrysostom (ca. 347-407) on Bishops

3.2 Chrysostom (ca. 347-407) on Lazarus and the Rich Man

3.3 Rules for Bishops and Clergy (ca. 880)

4. Early Monasticism

4.I The Life of St. Antony by Athanasius (ca. 356-362)

4.2 Basil to Gregory on Solitude (ca. 358-359)

4.3 Long Rules of St. Basil (ca. 356 )

4.4 Evagrius Ponticus's (345-399) Guide to Monastic Life

5. Syrian Stylites

5.I Life of St. Simeon (n.d.) 
5.2 Life of St. Daniel (409-493) the Stylite

6. Christianity and the Byzantine State

6.I Laws Governing and Reflecting the Faith (325-534)

6.2 Agathias (ca. 532-558) on Persian Religions

6.3 Procopius on the Immorality of Justinian (ca. 550)

6.4 Constantine Porphyrogenitus on Emperors (949)

6.5 Constantine Porphyrogenitus on Trappings (949)

7. Eastern Trends in Christian Theology

7.I Evagrius Ponticus (345-399) on Prayer

7.2 Maximus Confessor on Knowing God (ca. 630-634)

7.3 Maximus Confessor on Passions (ca. 630-633)

7.4 Maximus Confessor on Divine Love (ca. early 620s)

\section{PART II Growth and Schisms}

8. Holy Objects

8. I Marcellinus Discovers John the Baptist's Head (5 I 8)

9. Architecture-Hagia Sophia

9.I Procopius on Hagia Sophia (554-555)

9.2 Paul the Silentiary on Hagia Sophia (562)

Io. Missions to the North: Balkans and Rus'

IO.I Patriarch Photios on Latin Influence in Bulgaria (866)

I0.2 Pope Adrian II's (867-872) Epistle to the Slavs

I0.3 Tales from The Russian Primary Chronicle (ca. I I I6)

I I. Iconoclastic Controversy

I I.I Council of Constantinople on Images (754)

I I.2 The Second Council of Nicaea on Icons (787)

I I.3 Theodore the Studite (759-826) Refutes Iconoclasts

I2. Icons: Aesthetics and Forms, I Ioos-1600s

I 2.I Savior Acheiropoietos

I 2.I.I Acheiropoietos (I000s)

I 2.2 Christ Enthroned

I 2.2.I Christ Enthroned (I 400s)

I 2.3 Christ Pantocrator

I 2.3.I Christ Pantocrator (I 500s)

I 2.3.2 Christ Pantocrator Mosaic (ca. Io80-I Ioo)

I 2.4 Hodigitria

I 2.4.I Smolensk Hodigitria (I 500s)

I 2.4.2 Mosaic Icon with Virgin and Child (early I 200s) 
I 2.5 Loving-Kindness

I 2.5.I Vladimir Theotokos (ca. I I 3 I)

I 2.6 St. John the Forerunner

I 2.6.I Encaustic Icon of St. John the Forerunner (500s)

I 2.6.2 St. John the Forerunner (ca. I600)

I 2.7 St. George

I 2.7.I St. George the Martyr and the Dragon (I 400s)

I 2.8 Nativity of Christ

I 2.8. I Nativity of Christ (I 400s)

I 2.9 Annunciation

I 2.9.I Annunciation (I400s)

I 2.9.2 Annunciation (early I 300 )

I 2. IO Cross

I 2.IO.I Crucifixion (I 500s)

I 2.I0.2 Crucifixion (late I 200s)

I 2. I I Harrowing of Hell

I 2.I I.I Descent into Hell (ca. I495-I 504)

I 2.I 2 Holy Trinity

I 2.I 2.I Andrei Rublev, Holy Trinity (ca. I408-I425)

I 2.I 3 Heavenly Ladder

I2.I3.I Heavenly Ladder of John Climacus (late I ıoos)

I3. Church Music

I3.I St. Romanos, "Kontakion for Theophany” (500s)

I3.2 Sticheron Apostichon Idiomelon for St. Basil (700s?)

I3.3 Koukouzelis, “Grind His Teeth” (ca. I 280-I375)

I4. Liturgy

I 4.I Divine Liturgy of St. John Chrysostom (n.d.)

I 4.2 Nicholas Cabasilas on the Divine Liturgy (I 300 )

I 5. Monasticism and Rise of the Great Monastic Houses

I 5.I Theodore the Studite's Charge to Successors (826)

I 5.2 John Tzimiskes's Rules for Monastic Life (97I-972)

I6. Grants to Religions Institutions

I6.I Grant to the Monastery of the Holy Savior (I399)

I 6.2 Grant to the Trinity Monastery (ca. I392-I 427)

I6.3 Grant to the Cathedral of the Mother of God (I448)

I6.4 An Immunity Charter to a Monastery (ca. I432-I445)

I7. Hesychasm

I7.I Simeon the New Theologian (949-1022) on God's Light I7.2 Thomas Aquinas on God's Essence (ca. I265-I 274) 
I 8. Great Schism

I8. I Filioque

I 8. I. I Maximus Confessor (ca. 580-662) Defends the

Filioque

I 8.2 Claims of the Roman See

I 8.2.2 Chrysostom (349-ca. 407) on the Bishop of Rome

I 8.2.3 Pope Gregory III (73I-74I) on Peter's Successors

I 8.2.4 Donation of Constantine (ca. 750-850)

I 8.3 Charlemagne and the Pope Assert Themselves

I 8.3. I Charlemagne on Iconoclasm (ca. 790)

I 8.3.2 Notker on Charlemagne and Chant (883-884)

I 8.3.3 Pope Adrian I to Charlemagne on St. Peter (774)

I 8.3.4 Pope Adrian I on Submission (774)

I 8.4. Photian Schism

I 8.4.I Pope Nicholas I on Papal Jurisdiction (865 or 866)

I 8.5 Anathemas of I054

I 8.5. I Michael Cerularius on Unleavened Bread (I054)

I 8.6 Fourth Crusade

I 8.6. I Crusade through Western Eyes (I 203-I 204)

I 8.6.2 The Chronicle of Novgorod (IOI6-I47I) on the Sack I 8.7 Council of Lyons

I 8.7.I Byzantine Tract against the Council of Lyons (I 274)

I 8.7.2 Barlaam on the Council of Lyons (I339)

I 8.8 Rise of Islam and Turkish Expansion

I 8.8. I Emperor Debates Muslim Caliph (early 700s)

I 8.8.2 John of Damascus on Islam (ca. 700s)

I 8.9 Council of Ferrara-Florence

I 8.9. I Greek Prelates at Florence (I438 or I439)

I 8.9.2 Greek Delegates Return from the Council (I439)

I 8.9.3 Isidor on Ferrara-Florence (I 44 I)

I 8.9.4 The Nikonian Chronicle on the Arrest of Isidor (n.d.)

I9. Post-Conciliar Doctrine

I9. I Gregory Palamas's (I 296-I359) Confession of Faith

20. Russian Hermeticism

20.I Life of St. Sergei (n.d.)

2I. Rise of the Moscow Patriarchate

2I.I Legendary Origin of Muscovy (ca. I 523-I 533 )

2I.2 Stoglav Council (I 55 I)

2I.3 Iov's Installation as Patriarch (I600s) 
22. Literature of Appanage and Muscovite Orthodoxy

22.I Martyrdom of Boris and Gleb (IOoOs)

22.2 Descent of the Virgin into Hell ( I IOOs)

22.3 Father Isaac and the Devils (ca. I05 I-I074)

23. Working among Pagans

23.I Questions of Kirik (ca. I I30-I I 56)

\section{PART III Modernity and Upheavals}

24. Icon Painting: Practical Instructions

24.I Dionysius of Fourna, Painter's Manual (I730-I734)

25. Patriarch Nikon and the Old Belief

25.I Letter from Tsar Aleksei to Patriarch Nikon (I 652)

25.2 Nikon on Spiritual versus Secular Power (ca. I663)

25.3 Church Council Condemns Avvakum (I666)

25.4 Church Council Condemns Nikon (1666)

25.5 Church Council Condemns the Schism (I667)

25.6 Autobiography of Archpriest Avvakum (I672-I673)

25.7 Account of Avvakum's Punishment (I670)

25.8 Tale of Boiarynia Morozova (late I600s)

25.9 Old Believer Converts to Official Orthodoxy (I 893)

26. Later Russian Monasticism

26.I Instructions of St. Serafim of Sarov (I759-I 833)

26.2 Life in a Woman's Monastery (I 82I)

26.3 Pious Woman's Path to the Convent (I908)

27. Orthodoxy under Ottoman Rule

27. I Account of Russian Pilgrimage to Jerusalem (I9I3)

28. Modern Music Inspired by the Church

28. I Peter Tchaikovsky, Divine Liturgy (I 878)

28.2 Sergei Rachmaninov, "Vespers" (I9I 5 )

28.3 Igor Stravinsky, Symphony of Psalms (1930)

29. Orthodoxy in Nineteenth-Century Literature

29. I Pomialovsky (I 862-I 863), Seminary Sketches

29.2 Emmanuel Rhoides, Papess Joanna (I 866)

29.3 Nikolai Leskov, "Singlethought" (I 879)

29.4 Feodor Dostoevsky, The Brothers Karamazov

(I $878-\mathrm{I} 880$ )

29.5 Leo Tolstoy, "Father Sergei” ( ( 889 ) 
30. Orthodoxy in the Diaspora: Missions to Alaska 30.I Iosaf on Work in Alaska (May I795)

30.2 German on Conversions (May I795)

30.3 Missionaries and Merchants (I 8 May I795)

30.4 Missionary Oath (I 840s)

30.5 Innokenty Instructs Hieromonk Feofan ( 1853 )

3 I. New Theological Controversy: The Imiaslavtsy

3I.I Ilarion, In the Caucasus Mountains (1907)

3I.2 Review of Ilarion's Book (1907)

3I.3 Antony Bulatovich Defends Ilarion's Book (I9I2)

3I.4 Father Ilarion's Defense (ca. I9 I 2)

3 I.5 Antony Bulatovich Defends Ilarion (I9I3)

3I.6 Proofs that the Name of Jesus Is God (ca. I9I3)

3I.7 Statement Signed by the Imiaslavstvo (I9I3)

3I.8 Actions against Jerome's Supporters (I9I3)

3 I.9 Conclusions of Investigating Commission (I9I3)

31.10 Response from Kolokol (I9I3)

3I.I I Muratov's Review of Bulatovich's Book (I9I3)

3I.I 2 Ivolgin's Response (I9I3)

3I.I3 Archbishop Antony's Conclusions (I9I3)

3I.I4 Nikon Reports from Mount Athos (I9I3)

3I.I 5 Bulgakov's Reflections on the Affair (I9I3)

32. New Thinking and Church Reform

32.I Leo Tolstoy, The Kingdom of God Is Within You (I 894)

32.2 Solovyov on the Essence of Christianity (I89I)

32.3 Pobedonostsev on Democracy and Education (I 896)

32.4 Petition on Women to Sobor (I9I7-I9I 8)

\section{PART IV Revolutions and Reevaluations}

33. Russian Revolution

33.I Church Sobor's Response to the Decree (I9I 8 )

34. Soviet Propaganda

\section{I Texts}

34.I.I Mother of God as a Pagan Remnant (I930) 34.2 Photographs

34.2. I Antireligious Corner in an Elementary School

34.2.2 Christmas Festival of the Godless

34.2.3 Mummified Body of a Counterfeiter

34.2.4 Red Mass by the League of the Militant Godless 
34.3 Antireligious Posters

34.3.I Comrade Lenin Cleanses the Earth of Scum (I920)

34.3.2 Hodgepodge Mother of God (early I920s)

34.3.3 Temple of Machine Worshippers (early I920s)

34.3.4 Towards Complete Collectivization of the USSR!

(ca. 1930)

34.3.5 Religion Is Poison. Safeguard the Children. (I930)

34.3.6 Toxic Religious Imperialism (I930)

34.3.7 The Holy Yoke (I930)

34.3.8 Press Day (193 I)

34.3.9 Club Instead of Church (I93 I)

34.3.Io Thus Teaches the Church (I93I)

34.3.I I Letter from Heaven (I932)

34.3.I 2 Enough (n.d.)

34.3.I3 Church and Grain Procurements (n.d.)

34.3.I4 Glory to the Great Stalin (I950)

34.4 Antireligious Propaganda in Early Soviet Film

34.4.I Battleship Potemkin (I925)

34.4.2 October (1927)

34.4.3 Earth (1930)

34.5 Biography

34.5.I Aleksandr Osipov, "Through a Thousand Why's" (1966)

35. Church under Stalin

35.I Closing a Church (I930)

35.2 Stripping Christ the Savior Cathedral (1930)

35.3 Destruction of Christ the Savior Cathedral (I93I)

35.4 Imprisoning the Patriarch (1937)

35.5 Execution Order (1937)

35.6 Solzhenitsyn Accuses the Church of Complicity (1972)

35.7 Sergei Zheludkov Responds (Easter 1972)

36. Orthodoxy in Twentieth-Century Literature

36.I Vladimir Nabokov, "Christmas" (I925)

36.2 Anna Akhmatova, "Lamentation" (1944)

36.3 Anna Akhmatova, "Crucifixion" (1940-1943)

36.4 Angelos Sikelianos, "Agraphon"

36.5 Angelos Sikelianos, "Dionysus Encradled"

36.6 Nikos Kazantzakis, The Last Temptation of

Christ (I95I)

36.7 Greek Holy Synod Condemns Kazantzakis (I955) 
37.8 Boris Pasternak, "Poems of Yury Zhivago" (I959)

37.9 Aleksandr Solzhenitsyn, "Matryona's House” (I963)

37. Eastern Orthodoxy in Film

37.I Aleksandr Nevsky (1938)

37.2 Andrei Rublev (1966)

37.3 Repentance (1988)

37.4 The Last Temptation of Christ ( 1988 )

37.5 Island (2006)

37.6 Tsar (2009)

37.7 Burned by the Sun 2 (2010)

38. Women's Ordination

38. I Behr-Sigel on Women's Ordination (2000)

39. Orthodoxy and Ecumenism

39.I Georgy Florovsky on Limits of the Church (1933)

39.2 Germogen Condemns Roman Church (I948)

39.3 Florovsky on Historical Commonalities (1950)

39.4 Justin Popovich on Europe and Ecumenism (1974) 